\title{
Novel and Eco-Friendly Washing Agents to Remove Heavy Metals from Soil by Soil Washing
}

\author{
Zygmunt Mariusz Gusiatin* \\ Department of Environmental Biotechnology, Poland \\ *Corresponding author: Zygmunt Mariusz Gusiatin, Department of Environmental Biotechnology, Faculty of Environmental Sciences, Słoneczna Str \\ 45G, 10-719, Poland
}

Submission: 眥: March 29, 2018; Published: 眥April 20, 2018

\begin{abstract}
Soil washing is a remediation technology that can efficiently remove heavy metals from soil and decrease environmental risk. Due to the negative effect of conventional washing agents on soil quality, their replacement with novel, eco-friendly agents is necessary. This paper gives a basic presentation of the most promising washing agents that have high potential to be used at field scale: biodegradable chelators, biosurfactants, plant extracts, and dissolved organic matter including soluble low-weight organic matter and soluble humic substances. The main advantages of these novel agents are highlighted.
\end{abstract}

Keywords: Remediation; Chelators; Biosurfactants; Dissolved organic matter; Humic substances; waste

\section{Introduction}

Heavy metals are the most common contaminants of soil other than hydrocarbons, and their environmental impact is long lasting. Soil contamination with heavy metals is a global problem, and the main source of this pollution is the mining and metallurgical industries. The USA has more than 100 thousand contaminated sites, and over $70 \%$ of them are contaminated with heavy metals [1]. In Europe, heavy metals contribute to around 35\% of soil contamination, which is higher than the contribution of other pollutants like mineral oils (24\%), PAHs (11\%) or BTEX (10\%) [2]. Metals are non-biodegradable and they can accumulate in living organisms and cause harmful effects: $\mathrm{As}, \mathrm{Cd}, \mathrm{Cr}, \mathrm{Cu}, \mathrm{Ni}, \mathrm{Pb}$ and $\mathrm{Zn}$ are ranked on the list of the 275 most hazardous pollutants by the Agency for Toxic Substances and Disease Registry. Thus, there is a need to protect soils and remediate metal-polluted sites, as indicated by the European Commission's Thematic Strategy for Soil Protection and national regulations for environmental protection.

The main goal in remediation of metal-contaminated soils is to bring them into compliance with soil quality standards, which means excess metals must be removed from the soil. Heavy metals can be permanently removed from soil by soil washing, i.e. physical soil separation followed by chemical extraction of pollutants. Soil washing is still considered to be a useful method because metals can be removed efficiently and cleanup can be rapid. The traditional washing agents for metal removal include acids and chelating agents, especially EDTA [3]. Although these agents have a high extraction efficiency, they can cause ecological problems in the soil environment. Acids can change the soil structure, decrease soil productivity by causing massive nutrient loss and be toxic to soil microorganisms. Although chelators have recently attracted interest from researchers, conventional chelators such as EDTA or NTA cause concern because they can be toxic, they persist in the environment or are slowly transformed, and they can remobilize metals and radionuclides. In addition, these conventional chelators have a relatively high price. Soil washing can be a more attractive option if the washing agents are not hazardous and are easily available, or if they can be recycled and detoxified. Thus, it is necessary to identify and use chelating agents with better biodegradability $[4,5]$.

The key point to remember about the development of remediation technology for heavy-metal contaminated soils is that an economical and appropriate washing reagent can be found [6]. Recently, a new kind of chelating agent, N,N-bis(carboxymethyl)-Lglutamic acid (GLDA), has drawn the attention of researchers [7]. GLDA is produced from monosodium L-glutamic acid, which is a biobased, naturally occurring amino acid. In contrast to EDTA, GLDA is a "green chelator", which is readily biodegradable (>80\%) and nontoxic [8]. GLDA has four carboxylic acid groups and, combined with a centralized nitrogen atom, these carboxylate groups create strong multiple bonds with di- and trivalent metals ions [9]. In comparison to EDTA, GLDA tended to remove less soil organic matter, total and plant available ammonium, and exchangeable $\mathrm{K}, \mathrm{Na}, \mathrm{Ca}$, and $\mathrm{Mg}$, which supports the revitalization of the washed soils. Additionally, 
after removal of metals ( $\mathrm{Cd}, \mathrm{Pb}$, and $\mathrm{Zn}$ ), regenerated GLDA is nearly as effective as fresh GLDA [7]. Biosurfactants constitute the other group of eco-friendly washing agents, and their usefulness for remediation of metal contaminated soils has been known since before 2000. Biosurfactants are important agents in soil remediation due to their biodegradability, low toxicity and high selectivity for metal removal, as compared to other washing agents. The most commonly investigated biosurfactants are plant saponins and microbial rhamnolipids [10-12]. The advantage of saponin over rhamnolipids is the possibility of using saponin at a higher concentration and at a wide range of pHs. As a result, saponin can be recommended for treatment of not only light soils, but also soils with a high content of clay. However, saponin is a relatively expensive reagent. Its average price is about $\$ 800$ per $\mathrm{kg}$, which limits its wide application in remediation projects. In contrast, tannic acid is over 3 times cheaper. It is found in the bark and fruits of many plants, notably in oak species, sumac, and myrobalan [13]. It has been shown that tannic acid efficiently removes metals and arsenic from soils and can be used as a cost-effective substitute for saponin $[14,15]$.

A new trend in soil washing with plant biosurfactants is the use of plant extracts containing saponins instead of commercial powder products. With plant extracts, the operational costs of soil remediation are substantially lower than with commercial biosurfactants. Saponin extract from soapberry (Sapindus mukorossi L) removed heavy metals $(\mathrm{Ni}, \mathrm{Cr}, \mathrm{Mn}$ ) from soil more efficiently than commercial saponin, and depending on the type of metal and its total concentration, the efficiency of soil washing was $25-99 \%$ [16]. Tea saponin and water-extracted saponins from soapnut fruit pericarp also have potential for metal removal [17-19]. However, plant extracts do not always have a high metal-removal efficiency. Thus, it has been proposed to mix plant extracts with biodegradable low-weight organic compounds to improve process efficiency. For example, Cao et al. [20] found that the use of plant washing agents extracted with water from Coriaria nepalensis, Clematis brevicaudata, Pistacia weinmannifolia and Ricinus communisare is a feasible and eco-friendly method of removing heavy metals from soil. However, with a single application of these substances, removal efficiency was low. This led the authors to test the effect of adding biodegradable organic compounds (hydrolytic polymaleic anhydride (HPMA) and 2-phosphonobutane-1,2,4tricarboxylic acid (PBTCA)) to the solution of plant extracts. Removal of metals ( $\mathrm{Cd}, \mathrm{Pb}$ and $\mathrm{Zn}$ ) with this mixture was much better than with the plant washing agents alone, and when the effects of using the mixture were compared to those of using EDTA for soil washing, losses of $\mathrm{N}, \mathrm{P}$ and $\mathrm{K}$ were more moderate and the content of organic carbon in soil was substantially higher.

The use of dissolved organic matter (DOM) as a washing agent is a recent improvement in soil washing technology. Compared to commercial washing agents, DOM costs very little because it can be derived from various wastes or composts. The use of waste as a source of washing agents is a part of the circulation economy, in which waste serves as a resource for producing new products. DOM possesses multiple binding sites and has the ability to form highly stable and soluble organo-metallic complexes with heavy metals, which are desirable characteristics for a washing agent that will be used in soil washing technology. The type of extracting agent affects DOM composition, i.e. its content of non-humified or humified soluble organics. For example, a DOM solution that has been extracted from waste with distilled water contains low-weight soluble non-humic substances (e.g. sugars and proteins), whereas one that has been extracted with alkaline substances contains soluble humic substances. To avoid extracting soluble humic-like substances, the waste should first be treated with organic solvents to remove waxes and fats before alkaline extraction.

The available literature indicates that DOM in the form of soluble humic substances has high potential to be used as a washing agent to remove heavy metals from soils [21-23]. Soluble humic substances show good surface-active properties, such as decreasing the surface tension of water, and in this regard, they are similar to plant biosurfactants. Soluble humic substances are composed of humic acids (HA) and fulvic acids (FA). Generally, HA and FA have a similar structure, but they differ in molecular weight and content of functional groups. FA have a poorly developed aromatic nucleus and numerous side chains with oxygen-containing functional groups [24], and they contain more carboxylic groups than HA. The lower molecular weight of FA, due to their low degree of polymerization, and their higher content of functional groups, favor formation of more soluble, bioavailable and mobile complexes with HMs. The interactions of HA with metal ions result in the formation of strong metal-humate complexes. Composts and various kinds of waste are rich in not only soluble organics, but also nutrients. This means that using DOM as a washing agent can both remove heavy metals and fertilize the remediated soil by increasing the content of organic matter (humic substances) and nutrients.

In addition to composts and sewage, there are other sources of DOM. Wine-processing waste sludge and alkaline substances, including $\mathrm{KOH}, \mathrm{Na} \mathrm{OH}, \mathrm{Ca}(\mathrm{OH})_{2}$, and $\mathrm{Mg}(\mathrm{OH})_{2}$, were employed to prepare various DOM solutions for remediating a $\mathrm{Pb}$-contaminated cropland by soil washing $[25,26]$. The use of $\mathrm{Ca}(\mathrm{OH})_{2}$ and $\mathrm{Mg}(\mathrm{OH})_{2}$ successfully prevented washing-related losses of $\mathrm{Ca}^{2+}$ and $\mathrm{Mg}^{2+}$. Moreover, the percentage of $\mathrm{Pb}$ removed increased by an estimated $20 \%$ when $\mathrm{Ca}(\mathrm{OH})_{2}$ and $\mathrm{Mg}(\mathrm{OH})_{2}$ were used instead of $\mathrm{KOH}$. In addition to soil $\mathrm{pH}$, other indices of soil fertility were improved after soil washing with DOM. Some liquid waste can be used directly for remediating soil without the need for extracting DOM. For example, a diluted liquid fertilizer obtained from composting of food-waste (chicken wastes and vegetable debris) was used to prepare a DOM solution to remediate $\mathrm{Zn}$-contaminated soil [27]. The original DOM washing solution contained abundant $\mathrm{NH}^{+}, \mathrm{K}^{+}$and $\mathrm{P}$ ions, and the major functional groups that were present were carboxyl and amide groups. Double soil washing at $\mathrm{pH} 2$ and a concentration of $1.5 \mathrm{~g} / \mathrm{L}$ of this solution decreased $\mathrm{Zn}$ concentration below the threshold value, slightly decreased the soil $\mathrm{pH}$ and considerably increased the content of available macroelements in the soil.

Another example of an eco-friendly washing agent is a citric acid fermentation broth, which is a liquid waste from citric acid 
production [6]. This solution contains a variety of microbial metabolites derived from the three carboxylic acid cycle along with other components in the form of organic acids and surface active substances. This broth biodegrades well and creates less secondary pollution. Preliminary investigations have shown that this type of washing solution is highly applicable for removal of $\mathrm{Cd}, \mathrm{Cr}, \mathrm{Cu}$ and $\mathrm{Pb}$ from soil [6], and its efficiency is higher than that of a citric acid solution. In addition, citric acid fermentation broth has only a small effect on the mineral composition of the soil and does not destroy the framework of the soil system.

\section{Conclusion}

Soil washing technology continues to progress towards the use of environmentally friendly, cost-effective and easily available washing agents, which not only considerably decrease the degree of heavy metal pollution in soil, but also restore soil fertility. Washing agents derived from various wastes or composts are highly promising and show great prospects for practical application. Their use will have a considerable impact on the development of "green engineering" technologies and more remediation projects with such agents can be expected in the near future.

\section{References}

1. He Z, Shentu J, Yang X, Baligar VC, Zhang T, et al. (2015) Heavy metal contamination of soils: sources, indicators and assessment. J Environ Indic 9: 17-18.

2. Panagos P, van Liedekerke M, Yigini Y, Montanarella L (2013) Contaminated sites in Europe: review of the current situation based on data collected through a European Network. J Environ Public Health 2013: 1-11.

3. Ko I, Chang YY, Lee CH, Kim KW (2005) Assessment of pilot-scale acid washing of soil contaminated with As, Zn and Ni using the BCR threestep sequential extraction. J Hazard Mater 127(1-3): 1-13.

4. Reinecke F, Groth T, Heise KP, Joentgen W, Müller N, et al. (2000) Isolation and characterization of an Achromobacter xylosoxidans strain B3 and other bacteria capable to degrade the synthetic chelating agent iminodisuccinate. FEMS Microbiol Lett 188(1): 41-46.

5. Kołodyńska D (2011) Chelating agents of a new generation as an alternative to conventional chelators for heavy metal ions removal from different waste waters. In: Ning RY (Ed.), Expanding issues in desalination, InTech, Croatia, p. 424.

6. Zhang H, Gao Y, Xiong H (2017) Removal of heavy metals from polluted soil using the citric acid fermentation broth: a promising washing agent. Environ Sci Pollut Res 24(10): 9506-9514.

7. Wang G, Zhang S, Xu X, Zhong Q, Zhang C, et al. (2016) Heavy metal removal by GLDA washing: optimization, redistribution, recycling, and changes in soil fertility. Sci Total Environ 569: 557-568.

8. Kołodyńska D (2011) Cu(II), Zn(II), Co(II) and $\mathrm{Pb}(\mathrm{II})$ removal in the presence of the complexing agent of a new generation. Desalination 267(2-3): 175-183.

9. Dissolvine GL (2011) Technical Brochure. Akzo Nobel Functional Chemicals BV, Amsterdam, Netherlands.

10. Hong KJ, Tokunaga S, Kajiuchi T (2002) Evaluation of remediation process with plant-derived biosurfactant for recovery of heavy metals from contaminated soils. Chemosphere 49(4): 379-387.

11. Gusiatin ZM, Klimiuk E (2012) Metal (Cu, Cd and Zn) removal and stabilization during multiple soil washing by saponin. Chemosphere 86(4): 383-391.

12. Diaz MA, de Ranson IU, Dorta B, Banat IM, Blazquez ML, et al. (2015) Metal removal from contaminated soils through bioleaching with oxidizing bacteria and rhamnolipid biosurfactants. Soil Sediment Contam 24(1): 16-29.

13. Dai J, Mumper RJ (2010) Plant phenolics: extraction, analysis and their antioxidant and anticancer properties. Molecules 15(10): 7313-7352.

14. Gusiatin ZM (2014) Tannic acid and saponin for removing arsenic from brown field soils: mobilization, distribution and speciation. J Environ Sci 26(4): 855-864.

15. Gusiatin ZM, Bułkowska K, Pokój T (2014) Tannic acid as a cost-effective substitute for saponin in soil remediation. Environ Biotech 10(2): 66-72.

16. Maity JP, Huang YM, Fan CW, Chen CC, Li CY, et al. (2013) Evaluation of remediation process with soapberry derived saponin for removal of heavy metals from contaminated soils in Hai-Pu, Taiwan J Environ Sci (25): 1180-1185

17. Mukhopadhyay S, Hashim MA, Sahu JN, Yusoff I, Gupta BS (2013) Comparison of a plant based natural surfactant with SDS for washing of As (V) from Fe rich soil. J Environ Sci 25(11): 2247-2256.

18. Ye M, Sun M, Wan J, Fang G, Li H, et al. (2015) Evaluation of enhanced soil washing process with tea saponin in a peanut oil-water solvent system for the extraction of PBDEs/PCBs/PAHs and heavy metals from an electronic waste site followed by vetiver grass phytoremediation. J Chem Technol Biot 90(11): 2027-2035.

19. Wang Q, Liu X, Wang C, Zhang X, Li H, et al. (2015) Solubilization effect of surfactants on morphological transformation of cadmium and pyrene in co-contaminated soils. Water Air Soil Pollut 226: 1-9.

20. Cao Y, Zhang S, Wang G, Li T, Xu X, et al. (2017) Enhancing the soil heavy metals removal efficiency by adding HPMA and PBTCA along with plant washing agents. J Hazard Mater 339: 33-42.

21. Hartley NR, Tsang DC, Olds WE, Weber PA (2014) Soil washing enhanced by humic substances and biodegradable chelating agents. Soil Sediment Contam 23(6): 599-613.

22. Kulikowska D, Gusiatin ZM, Bułkowska K, Klik B (2015) Feasibility of using humic substances from compost to remove heavy metals $(\mathrm{Cd}, \mathrm{Cu}$, $\mathrm{Ni}, \mathrm{Pb}, \mathrm{Zn}$ ) from contaminated soil aged for different periods of time. J Hazard Mater 300: 882-891.

23. Rasmussen SB, Jensen JK, Borggaard OK (2015) A laboratory test of NOM-assisted remediation of arsenic and copper contaminated soils. J Environ Chem Eng 3(4): 3020-3023.

24. Stevenson FJ (1994) Humus Chemistry, genesis, composition, reactions $\left(2^{\text {nd }}\right.$ edn), John Wiley \& Sons Inc, Canada, USA, p. 512.

25. Liu CC, Chen GB (2013) Reclamation of cadmium-contaminated soil using dissolved organic matter solution originating from wineprocessing waste sludge. J Hazard Mater 244-245: 645-653.

26. Chen YM, Lin WH, Lin YA, Liu CC, Wang MK (2014) Remediation of leadcontaminated soil using dissolved organic carbon solutions prepared by wine-processing waste sludge. Geoderma 235-236: 233-239.

27. Chiang PN, Tong OY, Chiou CS, Lin YA, Wang MK, et al. (2016) Reclamation of zinc-contaminated soil using a dissolved organic carbon solution prepared using liquid fertilizer from food-waste composting. J Hazard Mater 301: 100-105. 
Creative Commons Attribution 4.0 International License

For possible submissions Click Here

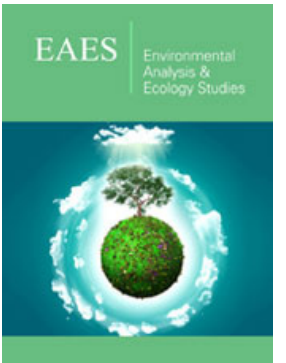

Environmental Analysis \& Ecology Studies

\section{Benefits of Publishing with us}

- High-level peer review and editorial services

- Freely accessible online immediately upon publication

- Authors retain the copyright to their work

- Licensing it under a Creative Commons license

- Visibility through different online platforms 